\title{
A cry in the dark: The howls of wolves in horror and heavy metal music
}

Amanda DiGioia, UCL School of Slavonic and East European Studies

\begin{abstract}
Deranged howling is a hallmark of wolves, horror texts and heavy metal music artists. This article discusses how wolves, heavy metal music artists and horror text directors use diegetic sound to interact with listeners. Wolves use howls in real life to communicate their location and identity to their pack-mates. Howling in heavy metal music is used either as a literal sound or as a metaphor, to unite their audiences as one cohesive pack, or as a reunion call. The sound of a wolf in horror films indicates something wicked coming along, often in the form of a werewolf or other nefarious monsters. This article shows how a cry in the dark in horror texts, heavy metal music, and in the wilderness is a means of communicating an emotion or identity to a mass human or lupine audience.
\end{abstract}

\section{Keywords}

diegetic sound

wolves

horror

howls

heavy metal music 
Heavy metal artists adopt and adapt the howling of wolves to unite and excite their audiences, much as horror film directors use diegetic sound to elicit a specific response- be it fear or excitement-from their viewers. Among wolves, howling is a form of communication. In this essay, the howling of real wolves is used to indicate how the use of their cries is reflective or not in the ways howling sounds are used in film and heavy metal music. Howling in heavy metal music is utilized both as a literal sound and as a metaphor, ranging from certain sonic effects to vocalizations. Each heavy metal howl sound produced, whether real or synthetic, has lupine tendencies threaded within it - growling, wavering and vibrato, which mimic and are associated with the wolf's cry. Horror film directors use howls to lead to a different emotion: fear. The sound of a wolf in horror films indicates something wicked coming along, often in the form of a werewolf or other nefarious monsters. Whether it be in heavy metal music, a horror text or in real life, the howl of the wolf is a source of communication to a wide audience.

In order to reflect on how howls are used in horror texts or in heavy metal music, the purpose of real-life wolf howling is provided as a baseline to draw from. Howling helps to keep wolves together physically (Harrington 2000: n.p.). Because wolves cover a vast territory to hunt and find food, they are often separated from one another. Howling is one form of communication that can travel long distances, making howling an effective form of contact between pack members. Additionally, howling can act as a reunion call, signalling to the pack that a pack member has returned (Harrington 2000: n.p.). Many studies suggest that wolves use howls for individual identification as well, as each wolf produces its own unique timbre when it howls (Palacios et al. 2007: 607). 
Howling is an act that is not without risk or danger for the wolf. When a wolf howls, the call is heard not only by its pack-mates but by all wolves within auditory range, including wolves in adjacent territories. If a lone wolf howls too close to the territory of another pack, that wolf is in jeopardy of being chased, attacked or killed by members of the rival pack (Harrington 2000: n.p.). For this reason, many older wolves will assess the costs and benefits of howling in any given situation. Younger wolves, particularly pups under four months of age, often howl indiscriminately, as they have not learnt to identify their older pack-mates or picked up the necessary life skills to discern when howling is appropriate (Harrington 2000: n.p.).A distinctive sound structure is found in the howling of wolves (Harrington 2000: n.p.). Howling is often lowpitched. Most howls have some degree of modulation, which occurs most frequently if the wolf is howling within a group chorus (Harrington 2000: n.p.). Modulation in the howl of a wolf in a group can be used to trick those listening that the pack is larger than it really is. If the sound is modulated rapidly enough, a pack of two wolves may sound like four or more. This phenomenon is called the Beau Geste Effect (Harrington 2000: n.p.). Many howls have a lower frequency that is coupled with harmonics, which causes the pitch of the howl to move higher or lower (Harrington 2000: n.p.). A study conducted on the howls of Iberian wolves indicates that the howls of that species are long (1.1-12.8s) harmonic sounds, with a mean fundamental frequency between 270 and $720 \mathrm{~Hz}$ (Palacios et al. 2007: 608). This study also indicated that there were similarities between the howls of North American wolves and the howls of Iberian wolves, the sole difference being that the frequency of the howl was lower for Iberian wolves (Palacios et al. 2007: 608). The alpha male of the wolf pack is more likely to howl confrontationally at (or approach) strangers, indicated by his howls becoming lower pitched and coarser in tone (Harrington 2000: n.p.). Lowering the pitch of a vocalization is almost a universal indicator of 
aggression in mammals (Harrington 2000: n.p.). These howls are often implemented to scare away intruders without the need for a face-to-face confrontation (Harrington 2000: n.p.). Thus, by howling in a lower pitch, a pack of wolves is indicating to an audience of intruders in the woods that they are there, and that they are ready to fight.

Wolves not only howl but also make other sounds, such as barking, whimpering or growling. Barking is used to raise a serious alarm, meaning that the wolf or the pack is in immediate danger (Harrington and Mech 1979: n.p.). Whimpering can indicate that it is time for pups to be nursed by their mother. Whimpering, if used by a wolf in a submissive position, can also indicate surrender to a more dominant member of the pack. Growling is used as a warning, either a threat against intruders to pack territory, or to indicate dominance to a member of its own pack (Harrington and Mech 1979: n.p.).

The howls and resonances of wolves have been described as 'eerie' for centuries (Manganiello 2009: 327). Folklore commonly portrays the wolf as conniving and evil. These beliefs are best illustrated in Aesop's Fables, which are believed to have been written in the mid to late sixth century BCE (Ashliman 2003: n.p.). Wolves in Aesop's Fables are devious, as they don sheep's clothing to walk undetected among the flock that they aspire to butcher. Aesop's wolves are also ruthless, as they have a tendency to devour helpless lambs, baby goats or ruin shepherd's livelihoods by slaughtering an entire flock. Aesop uses wolves as personifications of evil, as they are the key symbol in the fable whose moral is 'evil tendencies are early shown' (Ashliman 2003: n.p.). This stereotyping of wolves as malevolent beasts continues in the Christian New Testament. 'Beware of false prophets, which come to you in sheep's clothing, but inwardly they are ravening wolves' (King James Version, Gospel of Matthew 7:15). Aesop's thesis of 'The 
Wolf in Sheep's Clothing' is borrowed heavily in Matthew's Gospel, but the end result is the same: wolves are wicked and not to be trusted.

The ongoing tide of lupine loathing continued. At the end of the nineteenth century, North Dakotan Ben Corbin spat: 'The wolf is the enemy of civilization, and I want to exterminate him' (Hampton 1996: 126). A more recent study conducted in Wisconsin from 2001-2009 indicated that the 656 respondents had an increasing fear of wolves, which correlates to wolf populations rising due to conservation efforts within the state (Treves et al. 2013: 320). Given the long history of associating wolves and their cries with danger and fear, it is no surprise that horror writers and directors use the howls of wolves to set the stage for horrific events.

Irish author Bram Stoker used wolves to indicate to the readers of Dracula (1997) that something is not quite right with the titular Count. Shortly after noticing Dracula's 'protuberant teeth' and 'rank breath', Jonathan Harker sits silently with the Count by the fire. Jonathan notes:

There seemed a strange stillness over everything; but as I listened I heard as if from down below in the valley the howling of many wolves. The Count's eyes gleamed, and he said: -'Listen to them-the children of the night, What music they make!' Seeing, I suppose, some expression in my face strange to him, he added:'Ahh sir, you dwellers in the city cannot enter into the feelings of the hunter'.(Stoker 1997:24)

With the wolves, Dracula lets the reader know that he is no normal man, but kin to those feral hunters. The hunters' howling announces that they are near, just as wolves use howling in 
real-life situations. This sonic reference in Stoker's horror literature has carried over into film adaptations of the novel, causing the howls of wolves to unsettle viewers of the various incarnations of 'Dracula' throughout the decades. Film star Bella Lugosi made 'the children of the night' an iconic line in cinema when he donned a cloak and brought Dracula to life on the silver screen in 1931. The wolf acolytes that serve Dracula in Ted Browning's 1931 film cause audiences to fear him, as Jonathan Harker had, as soon as they hear their 'music' (or howls). By introducing this theme onscreen, Browning has transformed a communication device used by wolves into an indication to the audience that animals (or monsters) are near. Wolves and their musical call remain linked in Francis Ford Coppola's Dracula (1992), retaining the fear associated with the wolf children of the night and their musical call for an entirely new generation of film goers.

Other sinister connotations linked to the noises made by wolves can be found in horror films that feature werewolves or other lupine monsters. Part of the performance of these monsters relies on sonic guises. One of the finest examples of this can be found in John Landis'An American Werewolf in London (Landis, 1981). When two American students leave the safety of a pentagram-adorned pub called 'The Slaughtered Lamb' (this sounds like the name of a heavy metal band) to escape the socially awkward situation within, they forget to heed the warning that was given to them just before they left. The two students do not keep to the road, nor do they beware of the full moon shining above them. Distracted by their own conversation, they leave the road and begin to wander around the Yorkshire moors. They realize the magnitude of their mistake when they begin to hear a sinister sound echo across the moors, a howling sound that grows closer, and closer, until they are ultimately attacked. In this case, the director uses the howling of the supernatural werewolf to indicate to the audience that these characters are in 
trouble, and will soon face the consequences of their folly. They are frightened by the sound, and so are viewers.

A similar motif is used in The Howling (Dante, 1981). After a traumatic incident involving serial killer Eddie Quist, television anchor-woman Karen White heads for the colony, which is located in the secluded depths of the forest. Once at the colony, White discovers the residents are disturbingly eager to make her feel at home. As soon as darkness falls, White is haunted by unearthly howls that emanate from the depths of the wood. After enduring nights of torment from the cries in the dark, White ventures into the woods, only to make a horrifying discovery about the inhabitants of the colony: they are all werewolves, and harbour Eddie Quist, who is one of their own. The Howling's director, Joe Dante, much like John Landis, Tod Browning and author Bram Stoker before him, uses the howls of wolves, werewolves and other lupine creatures as a sign indicating to the audience that something treacherous is approaching. The same practice is used by real wolves, as howling is used to communicate the location of the animal to its pack and other animals around it.

Heavy metal music has a rich history of borrowing imagery and themes from horror movies. Wolves, howling and growling have long been staples in heavy metal music. A bridge between cinematic horror howls and heavy metal musicians' use of and references to howling can be found in Joe Johnston's 2010 remake of The Wolfman (Johnston, 2010). The howl of the lupine monster in The Wolfman comprises two metal music artists' voices, Gene Simmons of 'KISS' and David Lee Roth of 'Van Halen'. Johnston claimed that Roth's and Simmons' howls were the most useful of the sounds they collected in their quest to create the Wolman's 'spinetingling' howl (Staff 2010: n.p.).

Johnston expands on the inclusion of Gene Simmons and David Lee Roth in additional 
interviews. Johnston focuses particularly on Simmons in an interview done by Mark Salisbury, stating (Salisbury 2010: n.p.):

Gene Simmons came in and did some howls for us that were amazing. He has this amazing voice and range and sustainability. He did these howls that went on and on andon, and we kept thinking he's got to run out of breath any second, but he's got this amazing lung capacity....We were looking for really interesting voices and people who could interpret what a sound might be with their own voice, and we showed him the scenes where he (the Wolfman) howls and said, 'What would you do? It's an open mike, just do what you think is right...I forget who had the original idea, but we said, let's see what some of these rockers can do, you know'. There is no doubt that Gene Simmons' lung capacity can be attributed to years of touring with his band 'KISS,' a heavy metal group that is one of the world's bestselling bands of all time.(Reporter 2007: n.p., original emphasis)

Music journalist Jonathan Dick of Sterogum describes Simmons using his howling to both unite and entrance the masses during a KISS song entitled 'Rock and Roll All Nite', saying:

Even those completely unfamiliar with KISS have likely heard 'Rock And Roll All Nite'with its two very brief verses and endlessly repeated refrain echoing out to the roars, whistles, and excitement of the crowd...It's Gene Simmons howling like a gravel-throated 
lunatic, summoning up all manner of glam-rock darkness to entrance the masses.(Dick 2014: n.p.)

By 'howling like a gravel-throated lunatic', Gene Simmons announces his presence to his audience, much like real wolves announce their presence to their packs. The audience responds with vocalizations in turn, mirroring the actions of real wolves. The creators of the 2010 remake of The Wolfman recognized this bestial power within Gene Simmons, and it is no surprise that his howls were among the most useful to the production staff, successfully joining heavy metal music and thematic werewolf horror.

Peter Steele, the lead singer, bassist and principal song writer for the heavy metal band Type O Negative, adopted and adapted the howling of wolves for use in his music. This is evident in 'Wolf Moon (Inducing Zoanthropic Paranoia)', a track off Type O Negative's October Rust. 'Wolf Moon' has a melancholic symphonic wail, much like the howl of a wolf. Steele actually howls during the track in the sixth minute of the song. The meaning of the lyrics of 'Wolf Moon' is up for debate — common interpretations suggest it is an ode to werewolf sex or heterosexual intercourse during a woman's menstrual period. Regardless of how the lyrics are construed, 'Wolf Moon' undoubtedly includes howling and references to lupine behaviour. During live performances of 'Wolf Moon', the audience often sang along with Steele, adding their voices to his during the howl, much like actual wolves. Steele's bass voice indicated that he was the alpha of the pack. By howling in chorus, fans from around the world are reunited by the call of their alpha, Peter Steele, making live performances of 'Wolf Moon' similar to communication used by real wolves.

'LAI LAI HEI', a song by Finnish folk metal band Ensiferum, has lyrical content about 
wolves and vocal modulations resembling howling within the track. The lines of the song (in both English and Finnish) discuss a group of travellers singing and feasting in the forest. The forest is full of magical and mythical creatures, causing 'shadows to dance on the forest wall', and the raven's magic enthrals the woods. Ensiferum's song takes a dark turn at the end of the last stanza, in which the listener is informed that:

The morning will never rise again

The roaming wolves are howling for the dead

The roaming wolves are howling for the dead!

Lead vocalist Petri Lindroos then howls, using vocal modulations that wolves use when howling in groups. In both lyrics and howling, Ensiferum connects with the sonic horror of wolves by connecting the howls of wolves with death. The audience at the Ensiferum show has a clear lead, or alpha: Petri Lindroos. This is similar to the relationship between Type O Negative audience members and their alpha, Peter Steele. When audience members at an Ensiferum or Type O Negative concert raise their voices to join Lindroos' or Steele's howl, they do so as a form of unity, uniting as one pack and chorus. Live performances of 'LAI LAI HEI', with the howling by both Lindross and the audience, join fans from around the globe in a joyous reunion howl with their pack.

Another band that uses an actual wolf sound effect in their music is Finnish power metal act Sonata Artica. 'The Wolves Die Young', a track off Sonata Artica's 2014 album, entitled 
Pariah's Child, starts off with a snarling wolf sound effect, before continuing on to lyrical content discussing wolves overcoming a mythical tyrant queen who is plotting against them. Wolves are a central element to the lyrical content of many Sonata Artica songs. Additionally, Sonata Artica features wolves prominently within their album art. Sonata Artica vocalist Tony Kakko has said that wolves are the 'logo' of the band (Kakko and Portimo 2014: n.p.). Kakko has also stated that wolves in Sonata Artica songs can be viewed as metaphors, explaining '...Wolf is just once again a metaphor, for instance, for fear and processing it in your life. Fear make people do things. Or actually denying the fact that you fear something' (Kakko and Portimo 2014: n.p.). The wolf sounds chosen by Sonata Artica in the beginning of 'The Wolves Die Young' reflect their usage in the world of real wolves. Wolves often snarl to confront a type of danger (Wolfcenter.org n.d.: n.p.), relating to Kakko's assertion that wolves are also used as metaphors in Sonata Artica's songs. By having a snarling wolf to start off their track, Sonata Artica has indicated to their listener that they are about to face their fears. The vocalizations of wolves, and imagery of wolves themselves, are used by Sonata Artica to unite their fans as a pack, and to incite the reaction they desire from their audiences - forming a unified group that is willing to face and process their fears.

An additional heavy metal band that uses lupine references within their lyrical content as a way of collaborating with their audience to create a metaphor is Richmond, Virginia's Lamb of God (Grow 2015). '512', the second single off Lamb of God's eighth studio album, VII: Strum und Drang, references behaving in a lupine manner. Lead vocalist Randy Blythe growls the lyrics: 
Embrace the beast and shun the weak

Awake the primal one that sleeps inside

Or feel the shiv(er) running down your spine....

Blythe has explained in an interview for Rolling Stone that ' 512 ' is a song about his time spent in prison in the Czech Republic (Grow 2015: n.p.). Blythe was being held in prison while awaiting trial for manslaughter charges related to a fan's fatal fall at a Lamb of God concert in 2010. Blythe was ultimately found not guilty, but prior to the trial had remained in custody for five weeks, residing in cell 512 (Grow 2015: n.p.). Blythe began writing '512' during this incarceration, while reflecting on how this experience changed him (Grow 2015: n.p.).'Lycanthropic survival instincts/embrace the beast and shun the weak...' uses a werewolf metaphor to show that, in order to survive in a harsh prison world, an individual must accept the animalistic aspects inside of them, while spurning the civilized parts of their personality. 'Awake the primal one that sleeps inside...' is a reference to letting this repressed animalistic being that the outside world would shun awaken in a threatening situation; the moment sounds much like the transformation of an individual turning into a werewolf at the full moon. The play on words found in 'Or feel the shiv(er) running down your spine...' is a nod to the dread of death by being shanked. A shank is a weapon that is commonly found within prisons and is an object filed down to a sharp point by an inmate. The shiv is then used to stab other inmates. Prison changed Blythe, and Blythe chose a werewolf metaphor to communicate this change to his metal audience. The snarling vocalizations used by Blythe while singing ' 512 ' is reminiscent of communication used by real wolves: snarling by wolves is used as a communication tool and as a final warning before 
an attack (Wolfcenter.org n.d.: n.p.). The shiver he also references is a reaction of fear and horror to the threat of being attacked by a predator: in this instance, the choice is either to react as a man and die or to become a wolf-man and live.

German power-metal band Powerwolf used actual wolf sound effects on album tracks before, most notably on 'Mr. Sinister', the first song on Powerwolf's first length studio album, Return in Bloodred. The cover art of Return in Bloodred features a silhouetted werewolf in front of a city landscape howling, arms raised triumphantly towards the sky. Powerwolf has a song dedicated to werewolves featured in their 2011 album, Blood of Saints, aptly titled 'Night of the Werewolves'.

'Night of the Werewolves' has lyrical content that addresses the feelings of a werewolf when night approaches. The werewolf warns the listener:

See it's not a sermon, they can't call me back

And when the moon is high, we call the pack - we attack!

This is the night of the werewolves

Run for your life

This is the night

Never get out alive 
Powerwolf's werewolf also embraces its fate, refusing to be made into a victim by those who are sympathetic to the werewolf curse, as indicated by the lyric: 'See I'm not a sacred victim in despair, and when the fever calls, the pack is there - so beware!' (Powerwolf 2011).There are vocal modulations made by Powerwolf lead singer Atilla Dorn that are similar to those found within a wolf's howl when the final words of each of the first, second and third verse are sung. In the middle of the third minute of the track, a howling vocalization complete with modulation can be heard over a Dorn snarling lyrics in Latin. While Powerwolf's lyrical content of 'Night of the Werewolves' contains a warning, it is the werewolf itself warning the human listener to beware of it, and its pack, who are about to be unleashed once night falls. Mimicking real wolves, Powerwolf uses howling to specify to their listeners that the werewolves are near them, and by using the snarling tells them that they are also in grave danger.

Other musical genres have also used wolf or werewolf references as literal sound and a metaphor. Sam the Sham and the Pharaohs takes up the trope of a sexually aggressive man as a wolf in their song 'Li'l Red Riding Hood'. The wolf is also dedicated to wooing the eponymous heroine, and is even willing to keep a sheep suit on until he can prove himself as trustworthy to Little Red Riding Hood. For this reason, the howls of the wolf turn into 'baa' at the end of the song (Blackwell 1966). Ultimately, the howl in 'Li'l Red Riding Hood' is used as a comic effect, designed to make the audience chuckle at the wolf as he attempts to woo Little Red Riding Hood. This use of erotic howling and lupine metaphors in 'Li'l Red Riding Hood' stands in sharp contrast to the use of erotic howling in heavy metal music, as found in Type O Negative's 'Wolf Moon'. The howling in 'Wolf Moon' is not used for comedic effect. Instead, the howling in 'Wolf Moon' has a dual purpose: to foster community and to unleash the sexual animal within the man, whose sole purpose is to pleasure his female partner. 
The personality traits of the speakers in 'Li'l Red Riding Hood' and 'Wolf Moon' are also different. The wolf in 'Li'1 Red Riding Hood', in a nasally tenor, demands the attention of Little Red Riding Hood, commanding her to 'Look at me!' The wolfish speaker in 'Wolf Moon' does not demand the attention of the woman he is pursuing, unlike the wolf in 'Li'l Red Riding Hood'. Instead, the speaker in 'Wolf Moon' asks for a form of consent before pursuing her, as his deep bass voice rumbles: 'Woman may I know you're there?'. Unlike the Little Red Riding Hood in 'Li'l Red Riding Hood', who is spurning the wolf's advances, the female protagonist of 'Wolf Moon' is running through the woods towards the speaker in order to have intercourse with him. Peter Steele, the vocalist of Type O Negative, was attractive in a deliberately crafted animalistic way that has yet to be replicated by another singer in heavy metal music. Steele was an imitating figure, standing tall at a height of 6 $6^{\prime \prime}$. Moreover, Steele was muscular, tattooed, had canine teeth that were filed to look like fangs, and possessed long black hair down to his waist (Perrone 2010: n.p.). This did not stop audience members of either gender from being attracted to and not threatened by Peter Steele. Much like the woman in 'Wolf Moon', Type O Negative audiences ran towards the sensualist wolfish man, and not away from him.

Type O Negative's using a wolf's or werewolf's howl to suggest sexual intercourse has several explicit and implied thematic equivalents. Of these equivalents, The Howling IV (Hough, 1988), Wolves (Hayter, 2014) and 'The Company of Wolves' are films and short stories that stand out in favour of this thesis. Like in Type O Negative's 'Wolf Moon', The Howling IV: The Original Nightmare Wolves and The Company of Wolves (Jordan, 1984) each include a female character who is consenting to intercourse with a man who is unleashing his inner sexual animal via his howling. 
Angela Carter uses wolves and the howling of wolves to frequently invoke horror, sex and dread in 'The Company of Wolves', a short story found in her collection of fairy tale retellings, The Bloody Chamber (Carter 2015). Carter describes the wolf as a stealthy assassin, only visible by its eyes to those walking through the woods:

But those eyes are all you will be able to glimpse of the forest assassins as they cluster invisibly round your smell of meat as you go through the woods unwisely late. They will be like shadows, they will be like wraiths, grey members of a congregation of nightmare, hark! ...his long, wavering howl....an aria of fear made audible. The wolf song is the sound of the rendering you will suffer, in itself a murdering. (2015: 141)

Later on in the story Carter's heroine (a derivative of Little Red Riding Hood titular character) hears the howls of wolves outside her grandmother's cabin. Red Riding Hood describes the wolves as singing carols, 'howling in concert as if demented or deranged' (Carter 2015: 150). The Beau Geste Effect is also in place here, as the wolves sound and appear so numerous that Red Riding Hood cannot count them. Carter uses the howling of the wolf to transmit the feelings of fear and dread to the reader. Carter compares the wolves' howls to various forms of music (such as carols, arias and concerts), simultaneously using themes popular in heavy metal music. Shadows and a congregation of nightmare would be arguably welcome at any Black Sabbath or similar band's performances. Red Riding Hood remains unafraid, and burns her red cloak, standing naked before the wolf-huntsman (but not before ripping his shirt off for him). Instead of the wolf-huntsman devouring Red Riding Hood, it is she who sexually conquers him, and the 
story ends. Similarly, in the film version of The Company of Wolves, Rosaleen (the name given to Red Riding Hood in the film) compares the howling of wolves outside her grandmother's cabin to 'carols', as the sexual tension between her and the wolf-huntsman builds. Like in packs of real wolves, the wolves and werewolves in The Company of Wolves use howling to announce their presence to their pack-mates (in this case, it is the wolf-huntsman). The Company of Wolves ends with Rosaleen forcing the wolf to undress at gunpoint, shooting him, and consoling him as his pack abandons him. The next day when the villagers arrive to 'save' Rosaleen, they discover that she herself has become a wolf, a consort to the sexually attractive wolf-huntsman, whose pack had come to 'sing them carols' earlier that night. In the case of a story within The Company of Wolves, or in 'The Company of Wolves', itself, it is both partners who unleash the sexual beast inside them via the howling of wolves or werewolves.

The Howling IV: The Original Nightmare focuses on the main protagonist Marie, and her husband, Richard. Richard, like Peter Steele of Type O Negative, is indicated as an alpha by his appearance and vocal timbre: Richard has an ample amount of chest hair, voluminous brunette hair on his head, and a deep, husky voice. While Marie and Richard are indulging in foreplay in the bedroom, Marie hears the howling of wolves outside. Marie stops the heated moment between Richard and herself, asking him if he heard the howling in the woods outside. Richard claims that he did not hear the noise. Instead, Richard growls, 'You probably just heard the animal in me'. After Richard licks Marie's throat and resumes the interrupted foreplay, the scene abruptly cuts to the next day, with Richard and Marie strolling into town, hand in hand, indicating they are once again a happy couple, indirectly referencing the consummation of their foreplay. Like in 'Wolf Moon', the howling of a wolf or werewolf was a precursor to a passionate sexual act in The Howling IV: The Original Nightmare. 
Type O Negative's song 'Wolf Moon' similarly draws upon this connection between ‘curses' of lycanthropy and sex in 2014 Wolves, beyond sex. The main protagonist of Wolves, Cayden, is a werewolf who transforms into his wolf form whenever he is about to partake in sexual intercourse. This horrifies his human girlfriend, Lisa, who callously calls Cayden a 'monster'. This transformation into a werewolf during a sexual act is quickly reframed when Cayden has sex with a female werewolf named Angelina. Prior to the sex act, they have a discussion on lycanthropy, mulling over whether it is a blessing or a curse. Angelina remarks that 'But that's our big question right? Is it a gift? Or is it a curse?' When Angelina initiates sex with Cayden, he is hesitant. Angelina immediately understands why Cayden is resistant, observing, 'You're afraid the excitement, the adrenaline, might make you change'. Angelina then says, 'So what?' Angelina and Cayden then have growling, snarling and lycanthropic transformative sex. The discussion of a 'curse' before a sex act, and using consensual sex as a healing tool between werewolves, is also explored in 'Wolf Moon'. Prior to the implicated mating occurring between the male and female in 'Wolf Moon', Peter Steele sings:

Let me kiss the curse away,

Yourself in my mouth

Will you leave me with your taste?

By having sex with Angelina, Cayden embraces the animal inside himself, realizing that his lycanthropy is a gift. Cayden and Angelina both are no longer 'cursed' into being monsters. 
Instead, as werewolves, they are blessed: a benediction sealed by the act of their mating as both their human and wolf forms.

Warren Zevon's 'Werewolves of London' is a prime example of the difference between lupine references in rock music and heavy metal. The lyrical content of 'Werewolves of London' is riddled with social satire and social commentary. The werewolf protagonist of the song is a well-dressed violent murderer, as indicated by the lyrics: 'Better stay away from him, he'll rip your lungs out, Jim, I'd like to meet his tailor' (Zevon et al. 1978). The Werewolf of London also prowls around Soho while on the search for Chinese food. For much of the twentieth century, Soho was London's sex industry base (Topping 2013: n.p.). Relatedly, the term wolfish refers to an individual who is sexually licentious and lascivious. Naturally, the Werewolf of London would be seen in an area where he could satisfy these urges.

Howling is used in the chorus of 'Werewolves of London'. However, the howling in 'Werewolves of London' is not scary. This song, much like in 'Li'l Red Riding Hood', utilizes comedic howling, and is fuelled by absurd lyrical juxtapositions:

He's the hairy-handed gent who ran amuck in Kent

Lately he's been overheard in Mayfair

Better stay away from him

He'll rip your lungs out, Jim

I'd like to meet his tailor 
The howling found within 'The Werewolves of London' and 'Li'l Red Riding Hood' opposes the use of howling in heavy metal. The howling in 'The Werewolves of London' and 'Li'l Red Riding Hood' is not scary, although the howls are used to communicate that a wolf or werewolf is near. In rock or pop music, there is no unity with the werewolf. The werewolf is something to be feared. In these genres, the wolf or werewolf exists as an outside force, separate from the singer and their audience. This contrasts with the use of lupine metaphors in heavy metal music. In heavy metal music, lupine sounds and metaphors exist as a way to unify the speaker and the listeners. This communal effect is related to the nature of the group identity of heavy metal musicians and fans. Metal fans and bands both purposefully project an image of themselves as outside of, and perhaps threatening to, mainstream society. Those in the metal subculture are the wolves of the world, whereas those outside their scene are the sheep. This different relationship towards society can also correlate to the metal fans' different attitudes towards aggression and, possibly, sexuality.

Horror films also play off humorous juxtapositions of the lyrical content of music being played in comparison to what is occurring onscreen. An American Werewolf in London has several prime examples. The first is when Van Morrison's 'Moondance' is played while David Kessler (the American student survivor of a werewolf attack) has sexual intercourse with his former nurse, Alex Price. Prior to this occurring, David was met by the spectre of his dead travelling companion, Jack, who warned David that he is a werewolf and that he will transform at the next full moon. As a result of this, 'Moondance' is a tongue-in-cheek reference to what will occur to David shortly, as the full moon is rapidly approaching. This theme is continued throughout An American Werewolf in London, as the Creedence Clearwater Revival's 'Bad Moon Rising' is played the morning after a sexual encounter, which is also the day of the full 
moon. Sam Cooke's version of 'Blue Moon' is played during David's first werewolf transformation, the idyllic vocals providing the background music while David screams and violently transforms into a werewolf.

The lyrical content of each of the songs found in the soundtrack of An American Werewolf in London further bolsters the witty collocations between song and screen. 'Bad Moon Rising' features lyrics warning the listener that a 'bad moon is rising', 'trouble is on the way', and to not go outside that night, as the 'bad moon' foreshadows death for those that step underneath its beams. The first verse of 'Blue Moon' discusses how the speaker stands alone under the blue moon, without a love in their heart or a dream of their own, much like how those who transform into werewolves often kill the helpless humans who reside around them after their transformations, effectively leaving them all alone. 'Moondance' features references to the speaker's love shaking at his touch:

There and then all my dreams will come true, dear

There and then I will make you my own

And every time I touch you, you just tremble inside

In the context of 'Moondance', the lyrics reference a lover trembling in pleasure at the touch of a loved one. When taken out of context, the lyrics can denote the fear of being consumed by an individual who loves us, a fear that plays out in An American Werewolf in London. During David's final werewolf transformation, he goes on a horrific melee of 
destruction throughout London, killing more innocent individuals and horrifying the general public. Eventually, Werewolf David is cornered in an alley by the London Police. Alex barrels through a police barricade and faces David. Alex attempts to soothe the creature that David has become by telling him that she loves him. Werewolf David is momentarily placated, before snarling and lunging forward at Alex, where he is summarily shot and killed by the police. The snarling, as with real wolves, was Alex's final warning before a fatal attack. Alex breaks down, as the now human corpse of David lies before her, perforated with bullet holes. In werewolf form, David's dreams of touching Alex and making her his own are not romantically inclined. Instead, Werewolf David wants to consume Alex as a prey item, and claim her as his kill, and not as a romantic partner. Still, this occurs only when the song is applied in the context of $A n$ American Werewolf in London. This once again differs from the performance and application of lupine metaphors in heavy metal music. David had to transform into a werewolf in order for these metaphors to be made flesh in 'Moondance', whereas in heavy metal music the performers are already the wolf, or the wolf-man.

Howls are used by wolves and humans as a way to communicate, whether in real life, a horror text, or a heavy metal performance. By using diegetic sound, creators of horror texts cause their audiences to quiver with fear. Howling in heavy metal music is used either as a literal sound or as a metaphor, to unite their audiences as one cohesive pack, or as a reunion call. Wolves use howls in real life to communicate their location and identity to their pack-mates. A cry in the dark in horror texts, heavy metal music and in the wilderness is a means of communicating an emotion or identity to a mass human or lupine audience. 


\section{References}

Ashliman, D. L. (2003), 'Wolves in Aesop's Fables',

http://www.pitt.edu/ dash/aesopwolf.html.Accessed 22 September 2015.

Blackwell, R. (1966), 'Li'l Red Riding Hood' (sound recording), The MGM Singles (CD), Beverley Hills: MGM.

Browning, Tod (1931), Dracula, United States: Universal.

Carter, A. (2015), 'The Company of Wolves', Kelly Link (Introduction) The Bloody Chamber,New York City: Penguin, pp.-140-152

Cooke, S. (1960), 'Blue Moon' (sound recording), The Wonderful World of Sam Cooke (Vinyl), Los Angeles: Keen.

Coppola, Francis Ford (1992), Bram Stoker's Dracula, America: American Zoetrope.

Daily, D., 2007. The Classic Treasury of Aesop's Fables. $1^{\text {st }}$ ed. Philadelphia: Running Book Press Publishers.

Dick, J. (2014), 'The 10 Best KISS Songs', http://www.stereogum.com/1708986/the-10-bestkiss-songs/franchises/10-best-songs/. Accessed 19 April 2016. 
Fogerty, J. (1969), Bad Moon Rising (sound recording), (CD), San Francisco: Fantasy.

Grow, K. (2015), 'Lamb of God on how prison inspired raging new song “512”, Rolling Stone, 8 June, Available at: http://www.rollingstone.com/music/news/lamb-of-god-on-how-prisoninspired-raging-new-song-512-20150608 (Accessed 10/03/2016).

Hampton, B. (1996), 'Shark of the plains: Early western encounters with wolves', Montana: The Magazine of Western History, 46:1, pp. 2-13.

Harrington, F. H. (2000), 'What's in a howl?', http://www.pbs.org/wgbh/nova/wolves/howl.html. Accessed 11 September 2015.

Harrington, F. H. and Mech, D. L. (1979), 'Wolf howling and its role in territory maintenance', Behaviour, 68:3\&4, pp. 207-49.

Hayter, David (2014), Wolve, Canada: Ketchup Entertainment.

Hough, John (1988), Howling IV: The Original Nightmare, United States: Echo Bridge Home Entertainment.

Jones, N. (2014), 'Disappointed with the Sexless Into the Woods? Watch the Company of Wolves instead', http://www.vulture.com/2014/12/company-of-wolves-movie-neil-jordan.html. Accessed 19 April 2016. 
Jordan, Neil (1984), The Company of Wolves, United Kingdom: Hen's Tooth Video.

Kakko, T. and Portimo, T. (2014), interviewed by (Arto Mäenpää), Exclusive: Sonata Arctica Interview about 'Pariah's Child' 2014 (Subtitled), Kaaos TV, 7 February.

Manganiello, C. J.(2009), 'From a howling wilderness to howling safaris: Science, policy and red wolves in the American South', Journal of the History of Biology, 42:2, pp. 325-59.

Morrison, V. (1970),Moondance (sound recording), (CD), Burbank: Warner Bros.

Palacios, V., Font, E. and Márquez, R. (2007), 'Iberian wolf howls: Acoustic structure, individual variation, and a comparison with North American populations', Journal of Mammalogy, 88:3, pp. 606-13.

Perrone, P. (2010), 'Peter Steele: Towering, deep-voiced frontman of the goth-metal band Type O Negative', http://www.independent.co.uk/news/obituaries/peter-steele-towering-deepvoicedfrontman-of-the-gothmetal-ban-type-o-negative-1984990.html. Accessed 26 September 2015.

Powerwolf (2011), Night of the Werewolves (sound recording), (CD), Agoura Hills: Metal Blade Records. 

(2005), Return in Bloodred (sound recording), (CD), Agoura Hills: Metal Blade Records.

Reporter (2007), 'Gene Simmons shows his family jewels', http://www.theage.com.au/news/tv-radio/gene-simmons-shows-his-family-jewels/2007/12/10/1197135364624.html. Accessed 19 April 2016.

Rodgers, R., Hart, L. (1935), Blue Moon (sound recording), (CD), Detroit: Motown.

Salisbury, M. (2010), ‘Gene Simmons and David Lee Roth howled for "Wolfman” sound effects', http://herocomplex.latimes.com/uncategorized/gene-simmons-and-david-lee-roth-howledfor-wolfman-sound-effects/. Accessed 19 April 2016.

Staff, B. D. (2010), 'Gene Simmons, David Lee Roth provide “Wolfman’s” howl?!', http://bloody-disgusting.com/news/3175157/gene-simmons-david-lee-roth-provide-wolfman-showl/. Accessed 13 September 2015.

Stoker, B. (1997), Dracula, New York: Norton Critical Editions.

Topping, A. (2013), Soho Sex Workers Protest against Forced Evictions in London Red Light District, London: The Guardian . 
Treves, A., Naughton-Treves, L. and Shelley, V. (2013), 'Longitudinal analysis of attitudes toward wolves', Conservation Biology, 27:2, pp. 315-23.

Wolfcenter.org (n.d.), 'Snarl', http://wolfcenter.org/site/wolf-behavior/snarl.html_Accessed 19 April 2016.

Zevon, W., Marinell, L. and Wachtel, W. (1978), Werewolves of London(sound recording), (CD), London: Asylum Records.

\section{Contributor details}

Amanda DiGioia has recently earned her master's degree in women's studies at Southern Connecticut State University. Amanda is continuing her graduate education at the University College London School of Slavonic and East European Studies, effectively making her an American werewolf in London. Amanda's current thesis topic centres on how the female gender is conceptualized, perpetuated and performed in the Finnish heavy metal music scene.

E-mail: amandadigioia@gmail.coml 